\title{
Republic of Congo' Wood Products Exported to China: Insight of the Characteristics, Trends, and Perspectives for Sustainable Trade
}

\author{
Daniella Bienvenue Ondze, Min Tong, Richard K. Mendako \\ School of Economics \& Management, Northeast Forestry University, Harbin, China \\ Email: tongmin@nefu.edu.cn,daniella_ondze@yahoo.com,richardmendako@gmail.com
}

How to cite this paper: Ondze, D. B., Tong, M., \& Mendako, R. K. (2021). Republic of Congo' Wood Products Exported to China: Insight of the Characteristics, Trends, and Perspectives for Sustainable Trade. Open Journal of Forestry, 11, 135-152.

https://doi.org/10.4236/ojf.2021.112010

Received: February 18, 2021

Accepted: April 24, 2021

Published: April 27, 2021

Copyright () 2021 by author(s) and Scientific Research Publishing Inc. This work is licensed under the Creative Commons Attribution International License (CC BY 4.0).

http://creativecommons.org/licenses/by/4.0/ (c) (i) Open Access

\begin{abstract}
Wood products trade sector remains crucial for many countries' economies. This is also for the Republic of Congo (RC) where wood is the second most exported natural resource. In this study, we aimed to determine the predominant wood products exported from the RC to China from 2007 to 2019, analyze the trends related to this trade, compare the quantities of wood products exported to China and other destinations, and determine the perspectives for the sustainable trade. The descriptive study using graphs and tables, non-parametric technique Kruskal-Wallis, pairwise comparisons, and SWOT analysis made up the methodological basis for this study. IBM SPSS Statistics 26 software supported data processing. The results showed that logs were mainly exported to China, $92.585 \%$ of the three major wood products quantity (Logs, Wet sawnwood, and Dried sawnwood). Volume distributions between products categories differ significantly (Sig. $=0.000<\alpha=0.05$ ). Besides, a significant volume (69.32\%) was exported to China compared to the other destinations, and volume distributions between different destinations differ significantly (Sig. $=0.000<\alpha=0.05$ ). The SWOT analysis describes weaknesses, strengths, opportunities, and potential threats related to RC' wood products trade sector. The prospects for sustainable trade in wood products between the RC and China lie in establishing a good governance in the timber sector, supporting the emergence of domestic operators, and improving the business climate.
\end{abstract}

\section{Keywords}

Republic of Congo, China, Wood Products, Export, Sustainable Trade

\section{Introduction}

Forest resources are essential for the world's biodiversity and humanity needs 
(Siry, Cubbage, \& Ahmed, 2005). Forest has contributed to the industrial revolution and development, not only for wood-based industries but also for a pivot that propels industries' growth (Temu et al., 2008). As long as the world's population and economy continue to increase, forest products' overall demand will grow. Simultaneously, some countries' forested area is likely to decline (Simangunsong \& Buongiorno, 2001).

The Republic of Congo (RC), one of the Congo basin countries, has about 21 million hectares of forest land. Around 15 million hectares are nominated forestry concessions, and 4 million are protected areas (Tyrrell, Bare, Heindel, \& Arias, 2018). Therefore, the forestry sector occupies a prominent place, and wood is the second most exported natural resource in the country; the total value of primary wood products exports was around USD 406.7 million in 2015. Although set at $85 \%$ of the volume cut (Article 48 of the Forest Code), the fact remains that the transformation rate is only around 50\% (Malu-Malu, 2019). The Environmental Investigation Agency (EIA) reported that "this illegal trade caused the Republic of the Congo the loss of approximately eight hundred and twenty-three million USD between January 2014 and March 2018”.

Congolese wood's primary customers are Asian countries, notably China, which occupies the first position, and some European countries. The main combined factors that have contributed to the strengthening of trade relations between these two countries are that the RC, on the one hand, is endowed with significant oil and forestry resources. On the other hand, China needs these raw materials to ensure its economic growth (Bazika, 2009). At the end of the 2000s, when the demand for wood from the European Union (EU) decreased because of the economic crisis, China's demand remained solid.

Cooperation between the RC and China began in 1964 when China contributed to the construction of the first textile factory in Brazzaville (Bazika, 2008). This cooperation developed in the 2000s, marked by a new player, Chinese companies from the private sector. This trend corresponds to the internal transformations that China recorded in the 1970s. The aim of the cooperation between the Congo and China is to build a strategic partnership. During 2001-2005, Congo's exports and imports to China increased considerably, from $179.38 \%$ to $309 \%$ (Bazika, 2009). This country has become the leading destination for timber exports, both for those from the Congo Basin in Central Africa, the midland forests, the Southern and Eastern Africa (Weng et al., 2014), and the world's largest importer of Roundwood. The proportion of African wood exports destined to China grows from 35\% in 2000 to $78 \%$ in 2009, making wood one of the largest African commodity exports (Alexandre le grand, 2019).

Researches have been conducted to understand the dynamics of wood products in international trade. The dynamics of trade between RC and China motivated this study's achievement, as so far, few studies related to this issue are available.

Some studies focused on the improved law anti-fraud initiatives to attack global trade and illegal forest products (Cavanagh, Vedeld, \& Trædal, 2015). The 
EU has negotiated the VPA contracts with Cameroon and RC, Ghana, Indonesia, and Malaysia to combat illegal logging timber by developing the systems to monitor, verify, and authorize legal wood to cover timber and timber products exported to the EU and other destinations worldwide (EU FLEGT, 2020). It was stated that the first agreement was initialed with Ghana in September 2008 and Congo in May 2009 (Moiseyev, Solberg, Michie, \& Kallio, 2010), and which had a positive impact on timber exports in Cameroon (Brusselaers \& Buysse, 2018). The legal timber presented challenges for timber producers in Ghana and Indonesia, which bypassed the EU market's legality (Acheampong \& Maryudi, 2020). Besides, illegal logging represents $5 \%$ to $10 \%$ of the world's industrial Roundwood production, $12 \%$ of global softwood Roundwood trade, and $17 \%$ of the round hardwood trade (Creek, 2004). Another case is China's accession to the WTO that significantly increased imports of forest products and decreased domestic prices for lumber and wood products and the pulp, paper, and product related (Gan, 2004).

Several studies focused on determining the factors influencing the wood products international trade. The economies, distance, openness of the economy, population, forest resources, trading partners, policy to restrict logging, common border, free trade agreement, exchange rates, GDP, and GDPR, determined the trade in wood products (Buongiorno, 2015; Rahman, 2012; Vu, Tian, Zhang, \& Van Nguyen, 2019). The promotion of the Chinese language in partner countries has been stated to be the factor that can increase the trade flow (Nasrullah et al., 2020). The current and potential volume affected trade in forest products between EU countries and Turkey (Akyüz, Yildirim, Balaban, Gedik, \& Korkut, 2010). In other studies, the variations in GDP growth rates had a limited influence on the quantities supplied and traded due to limited wood supply potential. However, it affected actual prices, especially pulpwood and particulates (Trømborg, Buongiorno, \& Solberg, 2000). Using the Global Forest Products Model, the market balance has been forecasted regarding the quantities produced, consumed, and imported (Zhu, Buongiorno, \& Brooks, 2002).

Export policy on timber trade had been analyzed in some studies. The effect of export policy timber trade in Ukraine and the EU relieved that the wood industries positively impacted it, including a short-term period (Bublyk, Petryshyn, \& Medvid, 2019). The export tax and the decrease in the permitted annual reduction increased exports of value-added wood products (Donkor, 2003). Another study showed that the capital investment, labor, and institutional factors implemented under the Structural Adjustment Program increased wood production (Owusu, 2001).

The transformation of local wood by the total or partial stopping of exports in logs has become one of the Congo Basin countries' forest development's primary objectives. In Gabon, the public authorities opted for a total ban on exports of logs to better frame economic policy in 2010 (Kombila-Mouloungui, 2019). Before this period, Gabon was the 13th largest producer of tropical logs in the world and the third-largest exporter with a share of $16 \%$ of total exports. The 
volume of timber is exported in logs, sawnwood, and plating (Kaplinsky, Terheggen, \& Tijaja, 2011). The developing countries moved away from timber exports to exports of wood products processed, but the development project sector did not influence exports of processed wood products (Donkor, Vlosky, \& Attah, 2006).

So far, few studies had been focused on the trade of wood products between the RC and China. Understanding the characteristics, trends, and perspectives in this trade remains crucial to establish sustainable trade and public policy implications. This will help strengthen the trade relations between these two countries. We aimed to determine the predominant wood products exported from RC to China during 2007-2019, analyze the trends related to this trade, compare the quantities of wood products exported to China and other destinations, and determine the perspective for sustainable trade. The results revealed from this research are meaningful both for the scientific contribution and policy implications.

\section{Methods of Research}

\subsection{Data Source}

Data are from the Yearbook of the Ministry of Forest Economy of the Republic of Congo (Ministry of Forest Economy of the Republic of Congo, 2019). These data include statistics of the major wood products (logs, wet sawnwood, and dried sawnwood) exported from the RC to China and other major zones (Europe, Asia except China, America, and Africa) during 2007-2019. They are presented in export volume (cubic meter $\mathrm{m}^{3}$ ) by-product and destination; 2015 and 2017 are not part of the analysis because of the lack of related data. Besides, we drew another part of the secondary data from the literature relevant to this research.

\subsection{Data Analysis}

This study focuses on Insight of the Characteristics, Trends, and Perspectives for Sustainable Trade of the Republic of Congo' Wood Products to China. We achieved this through a descriptive study using graphs and tables; non-parametric alternative technique Kruskal-Wallis as our sample of data did not meet the strict parametric assumptions. Also, we conducted pairwise comparisons (multiple tests) by comparing significance values adjusted by the Bonferroni correction to the significance level $\alpha=0.05$ (Pallant, 2011). The Kruskal-Wallis Test (sometimes referred to as the Kruskal-Wallis H Test) is the non-parametric alternative to a one-way between-group analysis of variance. It enables the comparison of continuous variable scores for three or more groups. This test helped us detect the difference among groups (categories of wood products exported to China and other zones). It is similar to the Mann-Whitney U Test. IBM SPSS Statistics 26 software supported data processing.

To establish some sustainable trade perspectives, we also conduct a SWOT 
analysis based on the RC' major wood products exports to China. The SWOT analysis is an internal or external strategic planning technique used to help a business identify its strengths, weaknesses, opportunities, and threats (Koto, 2015). We established those four elements related to the Congo' wood products trade sector from the literature review.

\section{Results}

\subsection{Trends and Comparisons in RC' Major Wood Products Exported to China from 2007-2019}

Figure 1 highlights the major wood products that accounted for the Republic of Congo's exports to China (2007-2019). These products are divided into three categories: logs, wet sawnwood, and dried sawnwood. During this period, logs quantities exceed wet sawnwood and dried sawnwood, respectively. Trends in logs recorded $253 \%$ as increasing rate in 2009 and $-61 \%$ in 2008; wet sawnwood $309 \%$ in 2013 and $-47 \%$ in 2012; while dried sawnwood recorded $7100 \%$ in 2008 and $-97 \%$ in 2010 .

In Table 1, the total volume for all three categories of wood products exported from RC to China is estimated at 4,898,521.27 $\mathrm{m}^{3}$. Logs predominate with $4,535,278.31 \mathrm{~m}^{3}$, wet sawnwood occupied second place with a total volume of $314,042.45 \mathrm{~m}^{3}$, while dried sawnwood the last place with $49,200.51 \mathrm{~m}^{3}$. Logs are the dominant wood product exported from the Republic of Congo to China during this period, its most considerable quantity exported is $641,882.46 \mathrm{~m}^{3}$ in 2019 , and the minimum is $131,301.29 \mathrm{~m}^{3}$ during 2008. For wet sawnwood, $76,681.77 \mathrm{~m}^{3}$ (2019) and $8842.00 \mathrm{~m}^{3}$ (2012) are respectively the maximum and minimum quantities, while $12,060.00 \mathrm{~m}^{3}$ (2013) and $12.00 \mathrm{~m}^{3}$ (2007) are for the dried sawnwood.

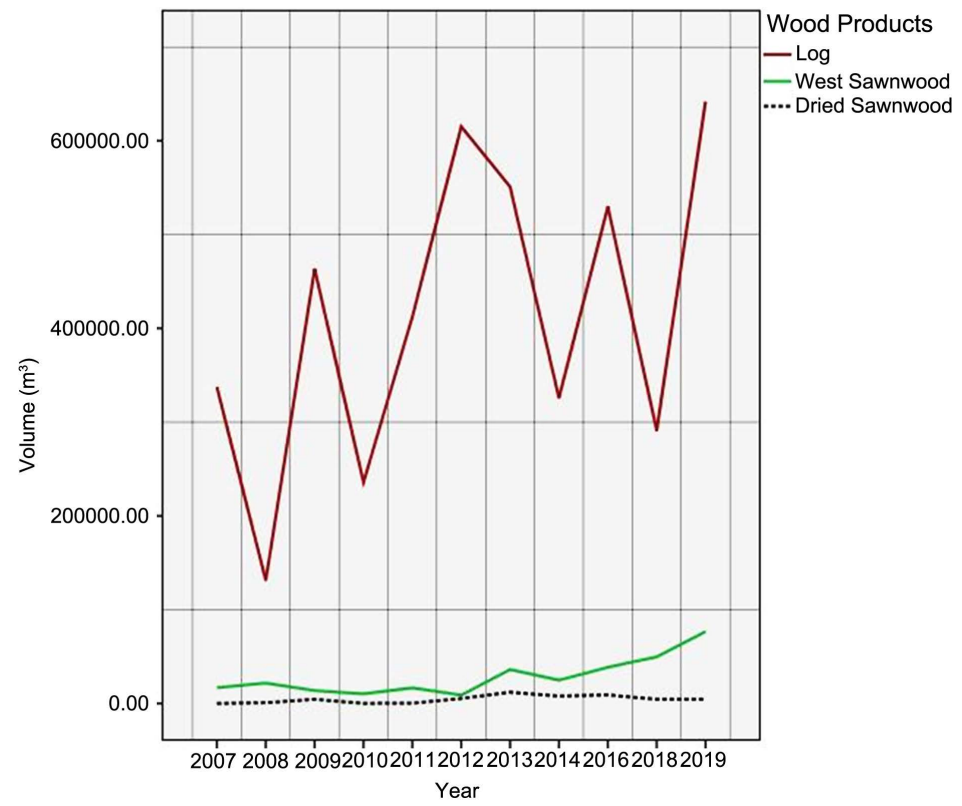

Figure 1. Quantities of RC' major wood products exported to China (2007-2019). 
Table 1. Summary statistics of RC' major wood products exported to China (2007-2019).

\begin{tabular}{cccccc}
\hline Products & Volume $\left(\mathrm{m}^{3}\right)$ & Average $\left(\mathrm{m}^{3}\right)$ & $\operatorname{Min}\left(\mathrm{m}^{3}\right)$ & $\operatorname{Max}\left(\mathrm{m}^{3}\right)$ & $\mathrm{SD}\left(\mathrm{m}^{3}\right)$ \\
\hline Logs & $4,535,278.31$ & $412,298.03$ & $131,301.29$ & $641,882.46$ & $163,525.03$ \\
Wet sawnwood & $314,042.45$ & $28,549.31$ & 8842.00 & $76,681.77$ & $20,511.90$ \\
Dried sawnwood & $49,200.51$ & 4472.77 & 12.00 & $12,060.00$ & 4008.22 \\
Total & $\mathbf{4 , 8 9 8 , 5 2 1 . 2 7}$ & & & & \\
\hline
\end{tabular}

In Figure 2, logs ratio is $92.59 \%$ of the total quantity, wet sawnwood $6.41 \%$, and dried sawnwood $1 \%$. This reflects the deficit in the forest industry's processing capacity in the RC, as in many tropical countries, and development in general. This context does not support sustainable trade, and the Congolese economy.

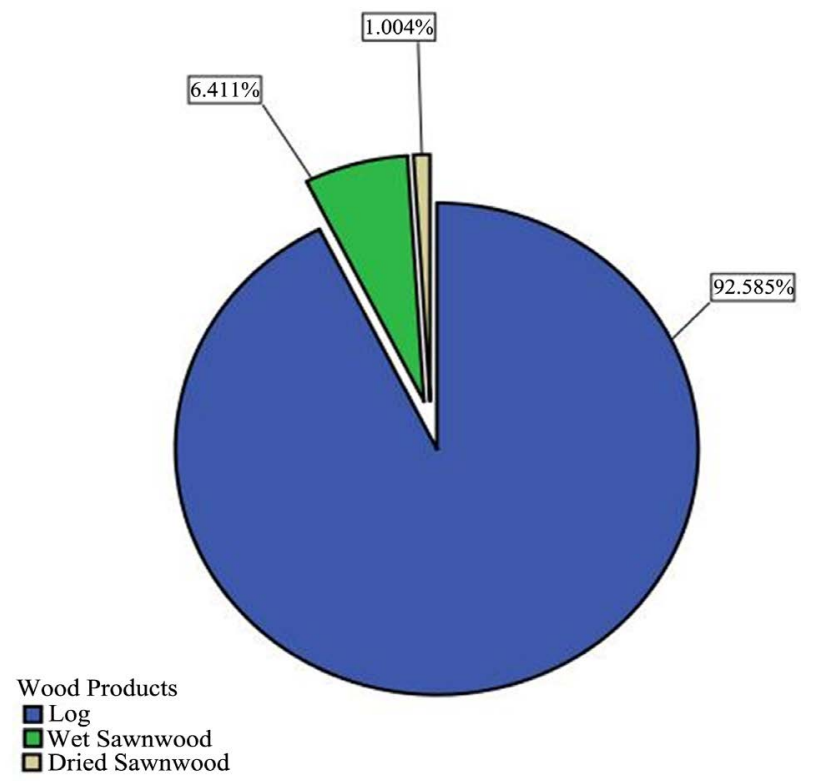

Figure 2. Ratio per Republic of Congo' major wood products exported to China (2007-2019).

\section{Comparisons of Congo' major wood products quantities exported to Chi-} na (2007-2019)

Based on Figure 3, the average volume of logs exported to China during this period is estimated at $412,298.03 \mathrm{~m}^{3}$, wet sawnwood $28,549.31 \mathrm{~m}^{3}$, and dried sawnwood $4472.77 \mathrm{~m}^{3}$.

\section{Kruskal-Wallis Test}

In Table A1 and Table A2, Kruskal-Wallis Non-Parametric Test relieved that the volumes between the three categories of wood products are not the same. The difference is significant at the significance level of 0.05 (Sig. $=0.000<\alpha=0.05$ ). Logs recorded a higher median score $(\mathrm{Md}=412,298.03)$ than the categories of wood products (Wet sawnwood Md = 21,742.00; Dried sawnwood Md = 4472.77).

Pairwise comparisons of wood products highlight the comparisons of volume distributions between the categories of wood products exported from RC to 
China (2007-2019). Based on Table 2, the distribution of logs volume differs significantly from the volume of dried sawnwood (Ad .Sig. $=0.000<\alpha=0.05)$; that of dried sawnwood differs significantly from wet sawnwood (Adj. Sig. = $0.034<\alpha=0.05)$; and distribution of $\log$ volumes differs significantly from that of wet sawnwood (Adj. Sig $=0.019<\alpha=0.05$ ).

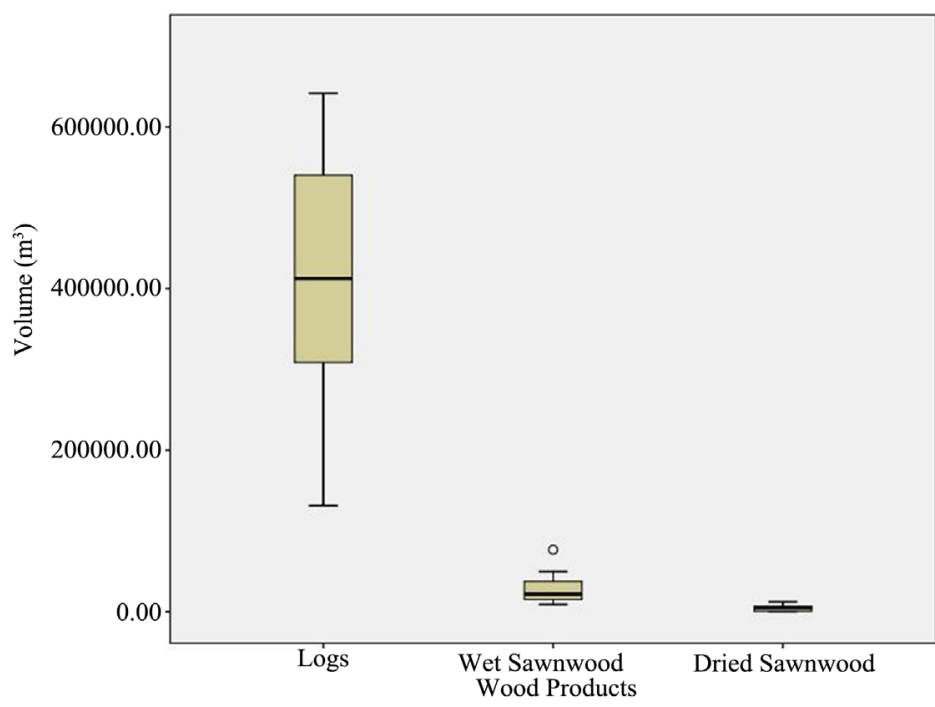

Figure 3. Boxplots of Republic of Congo' major wood products exported to China (2007-2019).

Table 2. Pairwise comparisons of wood products.

\begin{tabular}{cccccc}
\hline Sample 1-Sample 2 & $\begin{array}{c}\text { Test } \\
\text { Statistic }\end{array}$ & $\begin{array}{c}\text { Std. } \\
\text { Error }\end{array}$ & $\begin{array}{c}\text { Std. Test } \\
\text { Statistic }\end{array}$ & Sig. & $\begin{array}{c}\text { Adj. } \\
\text { Sig. }\end{array}$ \\
\hline Dried Sawnwood-Wet Sawnwood & 10.455 & 4.122 & 2.536 & 0.011 & 0.034 \\
Dried Sawnwood-Logs & 21.727 & 4.122 & 5.271 & 0.000 & 0.000 \\
Wet Sawnwood-Logs & 11.273 & 4.122 & 2.735 & 0.006 & 0.019 \\
\hline
\end{tabular}

Each row tests the null hypothesis that Sample 1 and Sample 2 distributions are the same. Asymptotic signi-

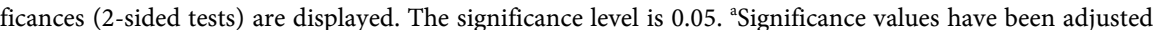
by the Bonferroni correction for multiple tests.

\subsection{Comparisons of Quantities of RC' Major Wood Products Exported to China and Other Zones (2007-2019)}

Figure 4 presents trends in the volumes of RC' wood products exported to the top 5 destinations (2007-2019). The quantity of wood products exported to China exceeds other zones; Europe comes in second place, third Asia (Except China); America fourth and Africa in the last position.

In Table 3, the total quantity exported to China is $4,898,521.27 \mathrm{~m}^{3}$; the minimum is $153,907.29 \mathrm{~m}^{3}$ during 2008 , and the maximum $723,037.00 \mathrm{~m}^{3}$ in 2019 . Europe's total volume is $1,429,819.50 \mathrm{~m}^{3}$ (minimum of $40,198.56 \mathrm{~m}^{3}$ in 2014 while the highest volume was $295,217.64$ in 2007). The other Asian countries imported an estimated total volume of $556,856.66 \mathrm{~m}^{3}\left(\min 15,838.67 \mathrm{~m}^{3}\right.$ in 2010 and $\max$ of $131,289.00 \mathrm{~m}^{3}$ in 2016). America imported a total volume of 


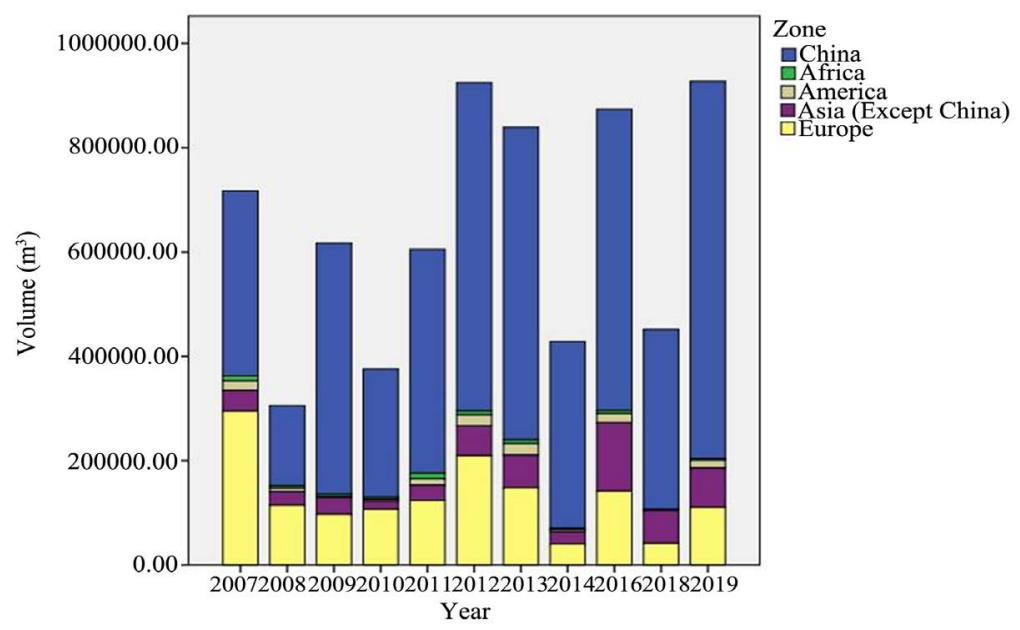

Figure 4. Quantities of RC' major wood products exported per zone (2007-2019).

Table 3. Summary statistics of the quantities of RC' major wood products exported per zone (2007-2019).

\begin{tabular}{cccccc}
\hline Zone & Volume $\left(\mathrm{m}^{3}\right)$ & Average $\left(\mathrm{m}^{3}\right)$ & $\operatorname{Min}\left(\mathrm{m}^{3}\right)$ & $\operatorname{Max}\left(\mathrm{m}^{3}\right)$ & $\mathrm{SD}\left(\mathrm{m}^{3}\right)$ \\
\hline China & $4,898,521.27$ & $445,320.12$ & $153,907.29$ & $723,037.00$ & $174,386.81$ \\
Africa & $59,325.58$ & 5393.23 & 883.11 & $10,541.00$ & 3123.24 \\
America & $122,334.26$ & $11,121.30$ & 773.42 & $22,271.00$ & 8055.62 \\
Asia (Expect China) & $556,856.66$ & $50,623.33$ & $15,838.67$ & $131,289.00$ & $33,052.20$ \\
Europe & $1,429,819.50$ & $129,983.59$ & $40,198.56$ & $295,217.64$ & $72,254.76$ \\
Total & $\mathbf{7 , 0 6 6 , 8 5 7 . 2 7}$ & & & & \\
\hline
\end{tabular}

$122,334.26 \mathrm{~m}^{3}\left(\min =773.42 \mathrm{~m}^{3}\right.$ in 2009 and $\max =22,271.00 \mathrm{~m}^{3}$ in 2013). A total volume of $59,325.58 \mathrm{~m}^{3}$ was exported to the African countries.

A total of 7,066,857.27 $\mathrm{m}^{3}$ were exported to the five main destinations. Each destination's ratios are presented in Figure 5: the largest proportion is China 69.32\%, Europe 20.23\%, Asia (except China) 7.88\%, America 1.73\%, and Africa

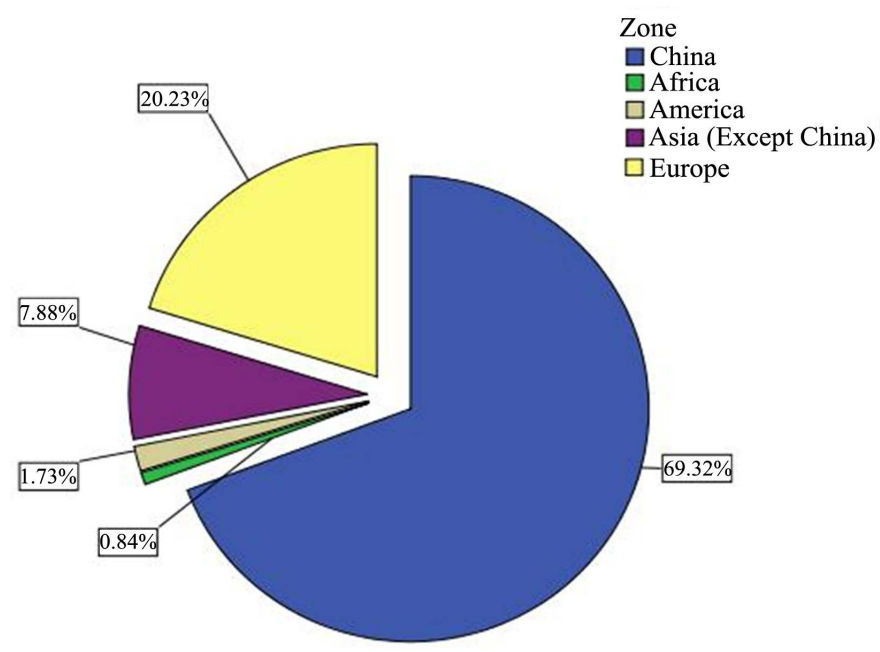

Figure 5. The ratio of the quantities of RC' wood products exported per zone (2007-2019). 
$0.84 \%$. As a result, China is the largest importer of wood products from the Republic of Congo during the period under study.

Comparisons of RC' major wood products quantities exported to 5 zones (2017-2019)

Based on Figure 6, China dominates with an average total volume of $445,320.12 \mathrm{~m}^{3}$; the average total volume exported to Europe is estimated at $129,983.59 \mathrm{~m}^{3}$, that to Asia (Expect China) $50,623.33 \mathrm{~m}^{3}$, to America $11,121.30$ $\mathrm{m}^{3}$ and Africa $5393.23 \mathrm{~m}^{3}$.

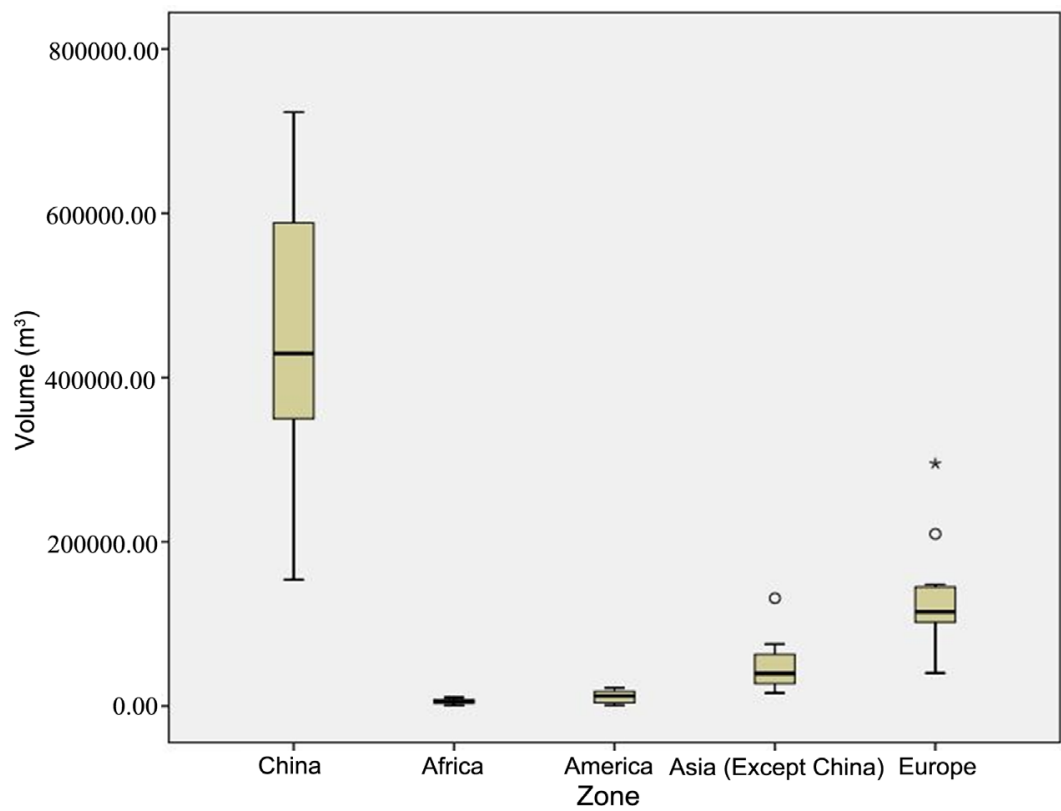

Figure 6. Boxplots of RC' major wood products exported to 5 zones (2007-2019).

Table 4. Pairwise comparisons of zones.

\begin{tabular}{cccccc}
\hline Sample 1-Sample 2 & $\begin{array}{c}\text { Test } \\
\text { Statistic }\end{array}$ & $\begin{array}{c}\text { Std. } \\
\text { Error }\end{array}$ & $\begin{array}{c}\text { Std. Test } \\
\text { Statistic }\end{array}$ & Sig. & $\begin{array}{c}\text { Adj. } \\
\text { Sig. }^{\text {a }}\end{array}$ \\
\hline Africa-America & -4.273 & 6.831 & -0.625 & 0.532 & 1.000 \\
Africa-Asia (Except China) & -19.455 & 6.831 & -2.848 & 0.004 & 0.044 \\
Africa-Europe & -28.364 & 6.831 & -4.152 & 0.000 & 0.000 \\
America-Asia (Except China) & 40.182 & 6.831 & 5.882 & 0.000 & 0.000 \\
America-Europe & -15.182 & 6.831 & -2.222 & 0.026 & 0.263 \\
America-China & -24.091 & 6.831 & -3.527 & 0.000 & 0.004 \\
Asia (Except China)-Europe & 35.909 & 6.831 & 5.257 & 0.000 & 0.000 \\
Asia (Except China)-China & -8.909 & 6.831 & -1.304 & 0.192 & 1.000 \\
Asia (Except China)-China & 20.727 & 6.831 & 3.034 & 0.002 & 0.024 \\
Europe-China & 11.818 & 6.831 & 1.730 & 0.084 & 0.836 \\
\hline
\end{tabular}

Each row tests the null hypothesis that Sample 1 and Sample 2 distributions are the same. Asymptotic signi-

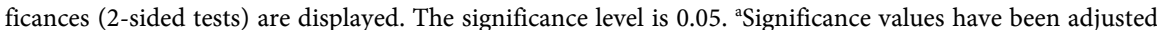
by the Bonferroni correction for multiple tests. 


\section{Kruskal-Wallis Test}

In Table A3 and Table A4, the Kruskal-Wallis test reveals a significant difference between volume distributions of 5 zones at the significance level $\alpha=0.05$ (Sig. $=0.000<\alpha=0.05)$. China recorded a higher median score value $(\mathrm{Md}=$ 429,311.03) than other zones (Europe Md = 114,762.51; Asia (Except China) Md = 39,781.48; America $\mathrm{Md}=12,309.00$ and Africa $\mathrm{Md}=4879.37$ ).

Based on Table 4, the difference is significant between the volume distributions of wood products exported to Africa and America (Adj. Sig. $=1.000>\alpha=$ 0.05). A significant difference is observed between volumes exported to Africa and Asia (Except China) (Adj. Sig. $=0.044<\alpha=0.05$ ) and between America and Europe (Adj. Sig. $=0.004<\alpha=0.05)$.

\subsection{SWOT Analysis Based on RC' Wood Products Exports to China for Sustainable Trade}

Sustainable trade participates in the international trading system to support the long-term domestic and global economic growth goals, environmental protection, and strengthening social capital. The definition of sustainability is quite a bit broader, including the three pillars of economic growth, social equity, and environmental protection, or what has come to be known in short-hand as the triple bottom line of profits, people, and the planet. The sustainability concept was first laid out in a landmark report issued by the UN's Bruntland Commission in 1987 (Olson, 2016; Keeble, 1988).

Based on the status of RC' wood products exports to China and relevant literature review, we analyzed the strengths, weaknesses, opportunities, and threats to give some perspectives for sustainable trade between these two countries (FAO, 2014; Kessy, 2019).

\subsubsection{Strengths}

- The Republic of the Congo has large areas of production forests, divided into forest management units (UFA), some of which contain forest exploitation units (UFE). The Congolese forest is, therefore, an economic potential, endowed with the considerable timber resources that China needs for its economy;

- The RC ranks 12th among countries with the largest FSC-certified forest area in the world and first in Africa. It has subscribed to many legal instruments of sub-regional and international scope in forest environmental management. This is an essential basis in the process of engaging in the legal certification of timber exported to China;

- Asian investors, mostly Chinese, are attracted to the logging of forest species with high commercial value (Okoume, Sapelli, etc.) in the Republic of Congo. Chinese logging companies are continually looking for business opportunities in the Republic of Congo.

\subsubsection{Weakness}

- RC mainly exports logs to China. This is due to Industrial furniture produc- 
tion which is almost non-existent, thus compromising the RC competitiveness against China;

- Indeed, the Republic of Congo has important legal bases and conventions to ensure the logging and export of sustainable timber to China. However, major weaknesses in governance and enforcement do not facilitate it, and many companies operate illegally;

- Local Processing Units do not have the financial capacity in industrial equipment investment and certification. These units are sometimes deprived of the raw material that is mainly destined for China. This context compromises the competitiveness of the RC and export revenues that could support its economy.

\subsubsection{Opportunities}

- The wood products trade between the RC and China presents a significant opportunity for these two countries' economies. China has become the largest importer of all products. Also, the RC is included in China's Silk Road project. This provides an essential basis for making this trade sustainable;

- Congo's adhesion to political, technical, and financial institutions working in favor of the Congo Basin forests (COMIFAC, OAB, OCFSA, RAPAC, OFAC, RIFFEAC, OIBT, ATIBT); Cooperation agreements with the European Union (EU); and conservation NGOs is an opportunity to strengthen its forest industry management and governance system, and set up the mechanism which can ensure the sustainability of timber exported to China.

\subsubsection{Threats}

- The export of raw wood products to China represents a shortfall in export revenues for the RC' economy. This is a relocation of the added value and intermediate consumption of the timber industry, which favors the fall in the GDP of the forest sector;

- Country risk is a significant challenge for the RC, as it is on the list of countries with fragile situations. These situations can be summed up in terms of vulnerabilities concerning international investment (the various factors, including political, economic, social factors that can lead to a risk of disaster during an operation with a foreign country). These situations could affect the sustainability of the wood products trade between the RC and China;

- RC's competitiveness with other countries endowed with timber resources and trading with China is a significant challenge that could change RC' wood products exports to China.

\section{Discussion}

Trends and comparisons in Republic of Congo' major wood products exported to China

For the three main categories of wood products selected for the study, a total 
volume of 4,898,521.27 $\mathrm{m}^{3}$ was exported from RC to China (2007-2019). Logs turn out to be dominant wood products with a volume of $4,535,278.31 \mathrm{~m}^{3}$ (92.585\%); wet sawnwood represents $314,042.45 \mathrm{~m}^{3}(6,411 \%)$ and dried sawnwood $49,200.51 \mathrm{~m}^{3}$ (1.004\%). Volume distributions between products categories differ significantly (Adj. Sig. $=0.000<a=0.05$ ), and Logs recorded a higher median score $(\mathrm{Md}=412,298.03)$. Trends in logs recorded $253 \%$ as increasing rate in 2009 and $-61 \%$ in 2008; wet sawnwood 309\% in 2013 and $-47 \%$ in 2012; while dried sawnwood $7100 \%$ in 2008 and $-97 \%$ in 2010 . Industries' needs and preferences in China could be the reasons for changing trends. Besides, the production and processing capacity of industries and institutional framework in the Republic of Congo.

The forestry policy report reveals that Congo exports almost half of its timber production in logs (FAO, 2014). Besides, it has been shown that practically all logs production is destined for export to Asia and Europe (Kessy, 2019). The export volume of finished and semi-finished products is still marginal. In 2019, RC exported $31.15 \mathrm{~m}^{3}$ of finished products to China. In 1993, Cameroon had produced $2.5 \mathrm{million} \cdot \mathrm{m}^{3}$ and exported 1 million (Chronique, 1999). Another study revealed that between 2004 and 2012, log exports to Cameroon increased by $173 \%$ to Europe and Asia (Mahonghol, Ringuet, Nkoulou, Amougou, \& Chen, 2016), China alone accounted for 55\% of average annual exports during this period (Mahonghol et al., 2016). Forest Trends has shown that Chinese imports are dominated by logs and sawnwood, accounting for $80 \%$ in volume and value of total wood product imports (Weiss et al., 2019). However, sawnwood accounted for New Zealand's exports (Turner, Katz, \& Buongiorno, 2008). Research in Zambia highlighted that $1.5 \%$ of production, mainly in untreated or low-quality sawnwood, is exported to neighboring countries, and 33\% of international product panels quality are standards ( $\mathrm{Ng}^{\prime}$ andwe, Ratnasingam, Mwitwa, \& Tembo, 2015).

In 2018, Cameroon was the largest supplier of sawnwood to France $(30,000.00$ $\left.\mathrm{m}^{3}\right)$, Gabon occupied the second position $\left(12,000.00 \mathrm{~m}^{3}\right)$, and the RC the third place $\left(6300.00 \mathrm{~m}^{3}\right)$ (France Bois, 2019). The increase in the volume of wood production and added value could be an essential factor for the economy while prohibiting logs' exports (Amoah, Becker, \& Nutto, 2009). In Vietnam, the furniture products, Roundwood, wood chips and particles, wood pulp, paper and cardboard, sawnwood, plywood, are mostly exported to Japanese, US, Korean, and Chinese markets (Vu et al., 2019). Other studies reported that about $90 \%$ of all Ghana exports were made up of sawnwood, veneer, and plywood in 2005, and $31 \%$ of the logs produced (Donkor, 2003). In 1998, China increased imports of logs from Gabon and Sarawak and plywood from Indonesia to meet its industries and domestic market (Kombila-Mouloungui, 2019).

These results corroborate ours, demonstrating the forest industry's low capacity in several tropical countries in general and developing countries. Therefore, international trade sustainability in these countries is called into question and their competitiveness in the global market. 


\section{Comparisons of quantities of RC' major wood products exported to China and other Zones}

The results show the China's supremacy in the RC' wood products exports. The total of $7,066,857.27 \mathrm{~m}^{3}$ were exported to 5 main destination: to China 4,898,521.27 $\mathrm{m}^{3}$ (69.32\%) were exported, Europe 1,429,819.50 $\mathrm{m}^{3}$ (20.23\%), Asia (Except China) 556,856.66 $\mathrm{m}^{3}$ (7.88\%), America $122,334.26 \mathrm{~m}^{3}(1.73 \%)$ and Africa 59,325.58 $\mathrm{m}^{3}$ (0.84\%). Volume distributions between destinations differ significantly (Sig. $=0.000<\alpha=0.05$ ) and China recorded a higher median score $(\mathrm{Md}=429,311.03)$ than other zones (Europe $\mathrm{Md}=114,762.51$; Asia (Except China) $\mathrm{Md}=39,781.48$; America $\mathrm{Md}=12,309.00$ and Africa $\mathrm{Md}=4879.37$ ).

China has become the world's largest tropical wood importer. In 2002, it imported 5 million $\mathrm{m}^{3}$ of sawnwood (Sénat-France, 2020). Some studies showed that in 1993, Cameroon's exports were destined for Europe and the Middle East until the Asian countries became major importers of logs in Cameroon (Chronique, 1999). In France, during 2011, an important volume of wood product was exported to China. The rest of the production was sent to Indonesia, Malaysia, or Vietnam. In Brittany, the maritime pine and Silka spruce were exported to China in raw logs (Sénat-France, 2020).

Between 2007 and 2017, China's direct imports from countries implementing or negotiating a VPA with the EU increased by $113 \%$ in volume and $136 \%$ in value. Five of the $15 \mathrm{VPA}$ countries are on the harmonized list of fragile situations: The Republic of Congo, the Democratic Republic of Congo, the Central African Republic, Ivory Coast, and Liberia. It was reported that from 2007 to 2017, China imported nearly $\$ 18$ billion worth of logs from 33 countries, with total or partial bans on log exports. This factor makes China the destination where the vast volumes of timber are much more exported. At the same time, Europe insists on provisions relating to timber legality.

The 2015 ITTO report showed that exports of tropical wood products to China have boomed, doubling their value by nearly \$EU 9 billion in 2013, from less than \$EU 4 billion in 2009. Indonesia, Malaysia, Thailand, and Vietnam export significant volumes of value-added wood products to the EU. Ghana has exported different timber varieties to around 40 countries, where Europe was the leading destination in 2005 (Organisation Internationale des Bois Tropicaux, 2015). It has been reported that, in 2003, Japan was the largest market for china's timber product export, and in 2004, the United stated became the leading destination of china's export timber product (Sun, Cheng, \& Canby, 2005). Demand in China and India, where it has increased sharply since 2009, has been focused on sawnwood and veneer logs, increasing the share of logs in the world's tropical timber trade from $14 \%$ in 2004 to $19 \%$ in 2013. China and India have become more critical than western markets, which traditionally prefer sawnwood (Organisation Internationale des Bois Tropicaux, 2015).

SWOT analysis based on RC' wood products exports to China for sustainable trade

Many tropical countries and those with abundant forest resources struggle to 
establish a sustainable trade system for their wood products despite their aspirations and the established legal framework. The case under analysis is that of the Republic of Congo, which has considerable forest resources and is located in the Congo Basin. Many opportunities are offered for this country: historic cooperative relations with China, Cooperation and agreements with the European Union (EU), and conservation NGOs. Significant weaknesses are damaging this sector: the forestry industry does not favor international competitiveness, meager industrial investment, and law enforcement challenges.

The supply of wood products can be a threat to the forestry industry sector of some countries. In Vietnam, timber supply has been considerably reduced, as in Laos, Capucia, Myanmar, and Cameroon. These countries have banned the export of logs and sawnwood from planted forests to protect forests ( $\mathrm{Vu}$ et al., 2019). On the other hand, the endowment of forest resources for the RC is a considerable asset.

Local processing and log export bans helped Brazil, Ghana, China, and Malaysia to derive considerable international trade revenues. Malaysia, in 2004, became the world's largest exporter of plywood over Indonesia (Kombila-Mouloungui, 2019). Measures on the quota for exports of logs in RC are among the institutional framework elements contributing to China's timber trade sustainability. The RC's endowment of forest resources is a strength to make this country competitive in wood products trade. However, the emergence and development of the forest industry is still a problem. Malaysia's achievement owes to its companies, which have obtained forest concessions in many countries of Asia and even other continents, for an area exceeding that of their country of origin, thus ensuring an external supply (Kombila-Mouloungui, 2019). The endowment of forest resources is, therefore, a significant force.

\section{Conclusion}

This study allowed the understanding of the trends, characteristics, and perspectives in wood products export from the Republic of Congo to China (20072019). Logs are predominant wood products exported to China $(92.585 \%$ of major products quantity), and wood products volumes differ significantly. Besides, China is the destination to which the huge wood products volume $(69.32 \%$ of five destinations volume) has been exported compared to the other destinations. The volume distributions between destinations differ significantly. The SWOT analysis describes the major weaknesses that plague the RC's wood products trade sector: weaknesses in governance and meager investment in the forest industry emergence. Strengths, opportunities, and potential threats were also discussed. The global timber trade sector remains a vital sector for the RC' economy, given the endowment of wood resources and its partners' network. The prospects for sustainable trade in wood products between the RC and China lie in establishing a good governance system in the timber sector, supporting domestic operators' emergence, and improving the business climate. 


\section{Acknowledgements}

We would like to acknowledge all those who contributed to this achievement.

\section{Conflicts of Interest}

The authors declare no conflicts of interest regarding the publication of this paper.

\section{References}

Acheampong, E., \& Maryudi, A. (2020). Avoiding Legality: Timber Producers' Strategies and Motivations under FLEGT in Ghana and Indonesia. Forest Policy and Economics, 111, Article ID: 102047. https://doi.org/10.1016/j.forpol.2019.102047

Akyüz, K. C., Yildirim, I., Balaban, Y., Gedik, T., \& Korkut, S. (2010). Examination of Forest Products Trade between Turkey and European Union Countries with Gravity Model Approach. African Journal of Biotechnology, 9, 2375-2380.

Alexandre le grand (2019). Comment en quelques années seulement, la Chine est devenue le plus grand débouché pour le bois des forêts du bassin du Congo-Conjoncture Economique (p. 17).

https://www.conjonctureseconomiques.net/2021/02/16/comment-en-quelques-anneesseulement-la-chine-est-devenue-le-plus-grand-debouche-pour-les-bois-des-forets-du-bassin -du-congo-2/

Amoah, M., Becker, G., \& Nutto, L. (2009). Effects of Log Export Ban Policy and Dynamics of Global Tropical Wood Markets on the Growth of Timber Industry in Ghana. Journal of Forest Economics, 15, 167-185. http://dx.doi.org/10.1016/j.jfe.2008.04.001

Bazika, J. C. B. (2009). The Impact of China's Trade Relations in Africa: The Case of the Republic of Congo (pp. 1-36). Brazzaville: Economic Policy Analysis Study and Research Center (CERAPE).

Bazika, J. C. B. (2008). Les relations économiques de la Chine avec la République du Congo. Brazzaville: Projet Collaboratif Du CREA.

Brusselaers, J., \& Buysse, J. (2018). Implementation of the EU-Cameroon Voluntary Partnership Agreement Policy: Trade Distortion, Rent-Seeking and Anticipative Behavior. Forest Policy and Economics, 90, 167-179. https://doi.org/10.1016/j.forpol.2018.02.008

Bublyk, M., Petryshyn, N., \& Medvid, R. (2019). Analysis of Export Policy of Timber Trade in the Conditions of International Economic Activity. Economic Analysis, 29, 5-11. http://dx.doi.org/10.35774/econa2019.03.005

Buongiorno, J. (2015). Monetary Union and Forest Products Trade-The Case of the Euro. Journal of Forest Economics, 21, 238-249. http://dx.doi.org/10.1016/j.jfe.2015.09.005

Cavanagh, C. J., Vedeld, P. O., \& Trædal, L. T. (2015). Securitizing REDD+? Problematizing the Emerging Illegal Timber Trade and Forest Carbon Interface in East Africa. Geoforum, 60, 72-82. https://doi.org/10.1016/j.geoforum.2015.01.011

Chronique, L. A. (1999). Le Cameroun et l'Exportation des Grumes. Economic Trends, 262, 94-95.

Creek, S. (2004). "Illegal” Logging and Global Wood Markets: The Competitive Impacts on the US Wood Products Industry. USA: Seneca Creek and Associates and Wood Resources International. 
Donkor, B. N. (2003). Evaluation of Government Interventions in Ghana's Forest Product Trade: A Post-Intervention Impact Assessment and Perceptions of Marketing Implications (p. 165). https://digitalcommons.lsu.edu/gradschool_dissertations/3498/

Donkor, B. N., Vlosky, R. P., \& Attah, A. (2006). Influences of Government Interventions on Increasing Value-Added Wood Product Exports from Ghana (pp. 1-16). Baton Rouge, LA: Louisiana Forest Products Development Center.

EU FLEGT (2020). Facility, Republic of the Congo. https://www.euflegt.efi.int/en/news-2020

FAO (Food and Agriculture Organization of the United Nations) (2014). La politique forestiere de la republique du congo (2014-2025) (pp. 1-43). Rome: Food and Agriculture Organization of the United Nations.

France Bois (2019). Dossier spécial: Retour sur les importations de bois 2018 (pp. 1-21). Nogent-sur-Marne: Le Commerce International de Bois.

Gan, J. (2004). Effects of China's WTO Accession on Global Forest Product Trade. Forest Policy and Economics, 6, 509-519. https://doi.org/10.1016/S1389-9341(02)00118-1

Kaplinsky, R., Terheggen, A., \& Tijaja, J. (2011). China as a Final Market: The Gabon Timber and Thai Cassava Value Chains. World Development, 39, 1177-1190. https://doi.org/10.1016/j.worlddev.2010.12.007

Keeble, B. R. (1988). The Brundtland Report: "Our Common Future”. Medicine and War, 4, 17-25. https://doi.org/10.1080/07488008808408783

Kessy, N. (2019). Etat des lieux des acteurs du Secteur Privé de la Filière Forêt-Bois au Congo (pp. 1-97). Brazzaville.

Kombila-Mouloungui, M. A. G. (2019). L'arret de l'exportation des grumes au Gabon: enjeux et perspectives. Thèse de Doctorat, Paris: Universite de Pau et des pays de l'Adour École doctorale Sciences Sociales et Humanités.

Koto, M. N. (2015). Impact de l'Anthropisation au bloc Nord de la Reserve Forestière de Yoko par une Analyse Spatiale et SWOT. Mémoire: Faculté de Gestion des Ressources Naturelles Renouvelables. Université de Kisangani. République Démocratique du Congo.

http://cd.chm-cbd.net/biodiversity/biblio/publications-biotechnologiques/agronomie/i mpact-de-l-anthropisation-au-bloc-nord-de-la-reserve-forestiere-de-yoko-par-une

Mahonghol, D., Ringuet, S., Nkoulou, J., Amougou, O. G., \& Chen, H. K. (2016). Les flux et les circuits de commercialisation du bois: Le cas du Cameroun.

Malu-Malu, M. D. (2019). Bois Du Congo_l'Asie s'installe. https://www.lepoint.fr/Economie/Bois-Du-Congo-l-Asie-s-Installe

Ministry of Forest Economy of the Republic of Congo (2019). Yearbook (2019th ed.). Brazzaville: Ministry of Forest Economy of the Republic of Congo.

Moiseyev, A., Solberg, B., Michie, B., \& Kallio, A. M. I. (2010). Modeling the Impacts of Policy Measures to Prevent Import of Illegal Wood and Wood Products. Forest Policy and Economics, 12, 24-30. https://doi.org/10.1016/j.forpol.2009.09.015

Nasrullah, M., Chang, L., Khan, K., Rizwanullah, M., Zulfiqar, F., \& Ishfaq, M. (2020). Determinants of Forest Product Group Trade by Gravity Model Approach: A Case Study of China. Forest Policy and Economics, 113, Article ID: 102117. https://doi.org/10.1016/j.forpol.2020.102117

Ng'andwe, P., Ratnasingam, J., Mwitwa, J., \& Tembo, J. C. (2015). Wood and Wood Products, Markets and Trade. In P. Ng'andwe, J. Mwitwa, \& A. Muimba-Kankolongo (Eds.), Forest Policy, Economics, and Markets in Zambia (pp. 27-66). Waltham, MA: Academic Press. https://doi.org/10.1016/B978-0-12-804090-4.00002-1 
Olson, S. (2016). The Case for Sustainable Trade. https://www.hinrichfoundation.com/research/tradevistas/sustainable/sustainable-trade -policies/

Organisation Internationale des Bois Tropicaux (2015). Le commerce européen des bois tropicaux en mutation RÉSUMÉ à la Surveillance indépendante du marché. Yokohama: Organisation Internationale des Bois Tropicaux.

Owusu, J. H. (2001). Determinants of Export-Oriented Industrial Output in Ghana: The Case of Formal Wood Processing in an Era of Economic Recovery. Journal of Modern African Studies, 39, 51-80. https://doi.org/10.1017/S0022278X01003524

Pallant, J. (2011). SPSS Survival Manual: A Step by Step Guide to Data Analysis Using SPSS (4th ed.). Australia: Open University Press.

Rahman, M. M. (2012). Analyzing the Contributing Factors of Timber Demand in Bangladesh. Forest Policy and Economics, 25, 42-46.

https://doi.org/10.1016/j.forpol.2012.08.006

Sénat-France (2020). Exportation de grumes vers la Chine. https://www.senat.fr/questions/base/2013/qSEQ130405728.html

Simangunsong, B. C. H., \& Buongiorno, J. (2001). International Demand Equations for Forest Products: A Comparison of Methods. Scandinavian Journal of Forest Research, 16, 155-172. https://doi.org/10.1080/028275801300088242

Siry, J. P., Cubbage, F. W., \& Ahmed, M. R. (2005). Sustainable Forest Management: Global Trends and Opportunities. Forest Policy and Economics, 7, 551-561. https://doi.org/10.1016/j.forpol.2003.09.003

Sun, X., Cheng, N., \& Canby, K. (2005). China's Forest Product Exports: An Overview of Trends by Segment and Destinations (pp. 1-21). Washington, DC: Forest Trends.

Temu, A. B., Chamshama, S. A. O., Kung'u, J., Kaboggoza, J. R. S., Chikamai, B., \& Kiwia, A. M. (2008). New Perspectives in Forestry Education. 1st Global Workshop on Forestry Education, September 2007, Nairobi: World Agroforestry Centre.

Trømborg, E., Buongiorno, J., \& Solberg, B. (2000). The Global Timber Market: Implications of Changes in Economic Growth, Timber Supply, and Technological Trends. Forest Policy and Economics, 1, 53-69. https://doi.org/10.1016/S1389-9341(00)00005-8

Turner, J. A., Katz, A., \& Buongiorno, J. (2008). The Economic Implications of Illegal Logging for the New Zealand Forest Sector. New Zealand Journal of Forestry, 53, 20-25.

Tyrrell, M., Bare, M., Heindel, N., \& Arias, M. (2018). Global Forest Atlas (pp. 1-2). New Haven, CT: Yale University.

Vu, T. T. H., Tian, G., Zhang, B., \& Van Nguyen, T. (2019). Determinants of Vietnam's Wood Products Trade: Application of the Gravity Model. Journal of Sustainable Forestry, 39, 445-460. https://doi.org/10.1080/10549811.2019.1682011

Weiss, G., Lawrence, A., Lidestav, G., Feliciano, D., Hujala, T., Sarvašová, Z. et al. (2019). Research Trends: Forest Ownership in Multiple Perspectives. Forest Policy and Economics, 99, 1-8. https://doi.org/10.1016/j.forpol.2018.10.006

Weng, X., Putzel, L., Kandulu, M. M., Ekman, S. S., Zafinikamia, M. B., Assembe-Mvondo, S. et al. (2014). The Africa-China Timber Trade: Diverse Business Models Call for Specialized Policy Responses. No. 28, Bogor: Center for International Forestry Research.

Zhu, S., Buongiorno, J., \& Brooks, D. J. (2002). Global Effects of Accelerated Tariff Liberalization in the Forest Products Sector to 2010. No. 534, Portland, OR: Pacific Northwest Research Station. https://doi.org/10.2737/PNW-RP-534 


\section{Appendix}

Table A1. Test statistics ${ }^{\mathrm{a}, \mathrm{b}}$ (Major wood products exported to China).

\begin{tabular}{cc}
\hline & Volume \\
\hline Chi-Square & 27.801 \\
$\mathrm{df}$ & 2 \\
Asymp. Sig. & 0.000 \\
\hline
\end{tabular}

${ }^{\mathrm{a} K r u s k a l}$ Wallis test; ${ }^{\mathrm{b}}$ Grouping variable: Wood products.

Table A2. Report (Major wood products exported to China).

\begin{tabular}{ccc}
\hline Volume & & \\
\hline Wood Products & N & Median \\
\hline Logs & 11 & $412,298.03$ \\
Wet Sawnwood & 11 & $21,742.00$ \\
Dried Sawnwood & 11 & 4472.77 \\
Total & 33 & $21,742.00$ \\
\hline
\end{tabular}

Table A3. Test statistics ${ }^{\mathrm{a}, \mathrm{b}}$ (Zones).

\begin{tabular}{cc}
\hline & Volume \\
\hline Chi-Square & 47.698 \\
$\mathrm{df}$ & 4 \\
Asymp. Sig. & 0.000 \\
\hline
\end{tabular}

${ }^{\mathrm{a}}$ Kruskal wallis test; ${ }^{\mathrm{b}}$ Grouping variable: zone.

Table A4. Report (Zones).

\begin{tabular}{ccc}
\hline Volume & & \\
\hline Zone & N & Median \\
China & 11 & $429,311.03$ \\
Africa & 11 & 4879.37 \\
America & 11 & $12,309.00$ \\
Asia (Except China) & 11 & $39,781.48$ \\
Europe & 11 & $114,762.51$ \\
Total & 55 & $39,781.48$ \\
\hline
\end{tabular}

